\title{
Parental Views of Minority Language Instruction in a Spanish Enrichment Program and for English Language Learners
}

\author{
Ani Shabazian \\ FRANCISCO RAMOS \\ Loyola Marymount University
}

Received: 5 May 2017 / Accepted: 30 September 2017

ISSN: $1697-7467$

\begin{abstract}
Forty parents of children enrolled in a Spanish Enrichment Program (SEP) at a Southern California university's children's center responded to a questionnaire inquiring on their attitudes toward their children learning Spanish, as well as the principles of bilingualism and the instructional use of minority languages with English Language Learners (ELLs). While parents appeared to support the SEP and the tenets of bilingualism, and value their children's development of bilingual skills, their support for the instructional use of minority languages with ELLs to help these students develop bilingual skills was not as strong. However, notably, a large number of participants were "not sure". This finding hints at the need for a concerted effort on the part of the SEP's faculty and staff to provide parents with more information on the principles of second language acquisition and bilingualism in general, in order to benefit all children, not just their own.
\end{abstract}

Keywords: Bilingual education, Spanish enrichment programs, English Learners, minority languages, parents' opinions

Creencias de padres sobre la enseñanza de lenguas minoritarias en un programa de enriquecimiento de español y de aprendizaje para estudiantes de inglés

RESUMEN: Cuarenta padres de niños matriculados en un Programa de Enriquecimiento de Español (SEP) en un centro de niños de una universidad del sur de California respondieron a un cuestionario que preguntaba sus opiniones sobre el aprendizaje del español por parte de sus hijos, así como los principios del bilingüismo y del uso de las lenguas minoritarias con los niños que están aprendiendo inglés (ELLs). Mientras los padres parecían apoyar el programa y los fundamentos del bilingüismo, y valorar el desarrollo de destrezas bilingües por parte de sus hijos, su apoyo al uso de las lenguas minoritarias para que estos estudiantes que están aprendiendo inglés desarrollaran sus destrezas bilingües no fue tan fuerte. Sin embargo, notablemente, un gran número de participantes "no estaban seguros" al respecto. Este resultado parece indicar la necesidad de un esfuerzo concertado por parte del personal del SEP para proveer a los padres con más información sobre los principios del aprendizaje de segundas lenguas y el bilingüismo en general que beneficie a todos los niños, no solamente los propios.

Palabras clave: Educación bilingüe, programas de enriquecimiento en español, aprendices de inglés, lenguas minoritarias, opiniones de padres. 


\section{INTRODUCTION}

Bilingualism is a widespread phenomenon in the world. In fact, more than half the population worldwide is estimated to speak more than one language (Harrison, 2007). In contrast, a large majority of the population in the United States remains monolingual in English (Kibler and Roman, 2013). Fortunately, many parents nationwide are seeking opportunities to expose their children to languages other than English (López, 2013), largely propelled by research highlighting the many advantages of bilingualism (Lao, 2004; Rodríguez, 2015; Ryan, 2005). With this in mind, the present study investigated parents' opinions about bilingualism related to two different situations: One involving their own children learning a minority language (Spanish in this case), and a second one involving the instructional use of primary languages with limited English proficient students. More specifically, the study attempted to answer the following questions: What are parents of children enrolled in a Spanish Enrichment Program's perceptions of their own children's exposure to a minority language (Spanish) in early childhood? What are parents of children enrolled in a Spanish Enrichment Program's perceptions of the instructional use of minority languages with limited English proficient students' during their schooling? This manuscript reviews the literature on early childhood bilingualism; describes some educational programs helping children develop bilingual skills; summarizes existing research on the use of minority languages with limited English proficient students; and presents its findings, followed by a discussion, and implications for further research.

\section{TheORETICAL FRAMEWORK}

\subsection{Bilingualism in Early Childhood}

Language acquisition is a complex process, which becomes even more magnified when another language is added into the fold. This is due to the fact that learning a new system entails gaining a command of linguistic and communicative competences that may vary significantly from the one already known (Bialystok, 2001). Additionally, individuals may experience interferences between the two linguistic systems. Thus, in her study of children learning German and French, English, or Italian simultaneously, for example, Müller (1998) found that the children applied rules from the latter languages to German, regardless of their dominant languages. Müller attributed these errors to the existing interaction between the languages the children were learning. Situations like this may lead individuals to be hesitant when facing the possibility of acquiring other languages or acknowledging the benefits of bilingualism, and spread myths and even develop negative attitudes toward this phenomenon (McCardle, 2015).

Research findings, however, have consistently shown the positive impact of bilingualism on higher executive functions, i.e., multi-tasking (Bialystok, 2011; Yang, Yang, \& Lust, 2011), creativity (Adi-Japha, Berberich-Artzi, and Libnawi, 2010), spatial perspective taking (Greenberg, Bellana, and Bialystok, 2013), and conflict resolution tasks (Carlson and Meltzoff, 2008). More importantly, these advantages are noticed as early as the first few months of children's lives (Ferjan Ramírez, and Kuhl, 2017; Kovacs and Mehler, 2009). 
Research further illustrates second language acquisition's strong impact on children's oral and social development during the early years (Shonkoff and Philips, 2000). Thus, children's communicative competence emerges within the context of the primary caregiver-child relationship as early as the first year of life of the latter (Sachs, 2005). Moreover, young children who engage in meaningful communication with trusted adults who validate and respond to their attempts at communication strengthen their neural pathways (Shore, 1997), develop their behavior, self-concept, and identity formation (Oller and Jarmulowicz, 2007), their socio-cognitive and socio-emotional development (Schieffeling and Ochs, 1986), and their cognitive and linguistic development in general (Oliva-Olson, Estrada, and Edyburn, 2017). In this regard, children in bilingual preschool classrooms seem to be at a more advantageous situation than their stay-at-home peers. Not only do the former appear to maintain their primary language proficiency at a comparable level to the latter; they also enjoy the advantage of becoming more proficient in a second language (Rodriguez, Diaz, Duran, and Espinosa, 1995).

The use of young bilingual children's home language in early childhood programs has a positive impact on their socio-emotional development (Halle, Whittaker, Zepeda, Rothenberg, Anderson, Daneri, Wessel, and Buysse, 2014). Maintaining one's home language helps maintain and strengthen familial bonds and supports the formation of self-concept and a strong sense of cultural identity (Oller and Jarmulowicz, 2007). In the early childhood program realm, the use of a child's home language reduces the risk of home language loss (Tannenbaum and Berkovich, 2005) and results in a higher level of closeness between teachers and non-native English speakers (Chang et al., 2007). Moreover, it reduces the chances of children becoming victims of peer aggression (Chang et al., 2007).

Consequently, it is important for early childhood educational pedagogical practices to consider using students' native languages for their impact on children's development across various domains (Bialystok and Senman, 2004; Garcia, 1995). The evidence for the overwhelming positive benefits of bilingualism highlights the crucial role that early childhood programs could play in allowing bilingual children to build their native language skills. The following section highlights how this can be done in highly structured environments, such as dual language preschools.

\subsection{Programs Promoting Bilingualism in Early Childhood}

The theoretical framework for dual language programs is based on the existing relationships between languages. The main premise of these programs is that knowledge of the world and literacy development in the primary language transfer rapidly to the second language. The more developed this background knowledge in the primary language, the more comprehensible the input heard and read in the second language. This results in a more accelerated and simplified second language acquisition process (Ramos and Krashen, 2013).

Díaz, Padilla, and Weathersby (1991) studied a bilingual preschool in El Paso aimed at helping children become proficient in Spanish and English before first grade. The teachers spoke both languages and used them simultaneously throughout the day. The findings of the study revealed how exposure to two languages increased children's usage of self-talk for self-regulation while processing tasks.

Christian (as cited in the National Center for Research on Cultural Diversity and Second Language Learning, 1994) highlighted two other programs serving early childhood students. 
The first one, housed at Coral Way Bilingual Elementary School, aimed for all students to become bilingual, biliterate, and bicultural. The second one, James F. Oyster Bilingual Elementary School, provided instruction in two languages from two co-teachers. In both cases, language instruction was integrated into the regular curriculum through content-based tasks, lessons, and assignments, instead of being taught as a separate, isolated, subject.

Rodríguez, Díaz, and Durán (1995) described a bilingual preschool program for low-income families in Northern California. The program provided direct-instruction in Spanish in the morning and exposed children to English in the afternoon in a less formal format. Spanish-speaking children learned English at a faster rate, while preserving their Spanish skills at the same level as Spanish-speaking children remaining at home. A similar result was obtained by Barnett, Yarosz, Thomas, Jung, and Blanco (2007), in their examination of a two-way immersion preschool program in a Northeastern city in the United States. The program made play a central element of the daily instruction of the 3- and 4-year-olds, both native English and native Spanish speakers comprising its student body.

Ryan (2005) investigated the Manchester Even Start preschool program, serving 3and 4-year-olds in Manchester, New Hampshire. Bilingual assistants in the program helped teachers "bridge" English to Spanish. Ryan found that the literacy scores of children in the program surpassed those of children enrolled in a comparable Title I preschool program with no bilingual teachers.

More recently, studies by Marian, Shook, and Schroeder (2013) revealed both minority language and majority language students benefiting from their enrolment in two-way programs by outperforming their peers enrolled in transitional and mainstream programs, in both Math and Language Arts. For their part, Anderson, Anderson, and Sadiq (2017) showed children participating in family literacy programs increased their early literacy knowledge in both the mainstream and their home languages.

These studies reveal the beneficial impact of programs exposing language majority and minority children to their native, as well as to a second language, in early childhood. Let's now examine whether this effect holds during the years of mandatory schooling for a specific population whose minority languages may not be frequently used for instructional purposes in the United States: English Language Learners (ELLs).

\subsection{Native Languages and ELLs}

The number of children attending United States schools who do not possess sufficient command of English to be placed in classrooms conducted exclusively in this language nears $9 \%$ of the total K-12 enrollment nationwide (EdGov, 2014). In order to meet the linguistic and academic needs of this population, officially labeled English Language Learners (ELLs), various programs have been implemented, which usually limit the amount of primary language instruction allowed in class (Ovando, Collier, and Combs, 2003), despite solid research showing the benefits of this instructional approach. Thus, large-scale evaluation programs by Ramírez (1992) or Thomas and Collier (2004); Greene's (1997) meta-analysis of studies comparing student performance in different programs; Krashen and McField's (2005) meta-meta-analysis, or McField and McField's meta-analysis of meta-analyses (2014) have highlighted the positive impact of the instructional use of ELLs' native language(s) on their acquisition of English. The larger effect sizes for bilingual education programs in Krashen and McField's study (2005), for example, led them to conclude that, "native-language instruction is part of the solution, not part of the problem" (p. 10). In short, using the 
students' primary languages in the classroom for instructional purposes results in an easier and faster acquisition of other languages.

Parents, the stakeholders most heavily invested in the success of their children, also seem to concur with this finding (Farruggio, 2010; Worthy and Rodriguez-Galindo, 2006). Farruggio, for example, found that more than three quarters of parents favored their children's maintenance of both the home language, values and identity. Similarly, the parents in Worthy and Galindo's study showed strong commitment to their own language and culture in view of their children's slow switch to English. Interestingly, similar opinions were expressed by parents of different ethnic groups, namely Hispanic (Shin and Gribbons, 1996), Korean (Shin and Kim, 1998), Chinese (Lao, 2004), or Hmong (Shin and Lee, 1996). Similar results have been found in more recent studies by Gerena (2011), Lee and Jeong (2013), or Parkes and Ruth (2011).

While some studies have investigated parents' opinions about their children's exposure to second languages in early childhood, and others have examined parents' opinions about native language instruction for ELLs, no article to date has investigated parents' opinions about both issues simultaneously. The present article attempts to fill this gap by shedding light on the following research questions:

What are parents of children enrolled in a Spanish Enrichment Program's perceptions of their children's exposure to a minority language (Spanish in this case) in early childhood?

What are parents of children enrolled in a Spanish Enrichment Program's perceptions of the use of ELLs' minority language(s) during their schooling?

\section{Methodology}

\subsection{Setting}

The present project was conducted at a Southern California university's Children's Center. Since its foundation, the Center has been a teaching and research facility for the university, providing Education and Psychology students with first-hand opportunities to work with young children on an individual basis, as well as in large- and small-group settings.

Depending on their respective ages, children may be placed in young infant ( 6 weeks to 22-months-old), older infant (12 months to 2.5-years-old), toddler (2 years to 3.5-yearsold), pre-schooler (3 years to 5-years-old), or mixed-age (for children 2.5 to 5 -years-old) classrooms. The latter illustrates the Center's belief that factors other than chronological age influence a child's development. Allowing children to interact with others of different ages, and learn at different rates, increases cooperation, diminishes stress, and eliminates stereotyping (Gerard, 2005).

It was in this context that a one-hour-a-week Spanish Enrichment Program (SEP) for two preschool and the mixed-age classrooms was established in the Fall of 2011, largely in response to the requests of parents wishing to expose their children to a second language. Taught by two Spanish proficient teachers, the SEP's initial student body of 60 children, expanded to 75 the following semester, once children in the toddler classroom enrolled in the program.

The SEP's overall curriculum emphasizes depth over breadth to ensure that children form concrete connections between the language used in class and their own life experiences. 
Lessons evolved from everyday topics such as colors, numbers, or shapes, to more complex conversations (within their logical simplicity) about family, home, and experiences through songs, books, and other developmentally-appropriate practices, as well as greetings and salutations to facilitate interactions. The SEP's faculty and administration are realistic in terms of children's development of fluency in Spanish given the limited extent of the program and therefore they encourage children to use Spanish outside the Center whenever they have a chance.

\subsection{Participants and Data Collection}

The Director of the Center, also a co-author of the study, contacted the 75 families with children in the SEP to inform them of the purposes of the project and request their participation in it. Her email to the parents attached a consent form and a copy of the Experimental Bill of Rights. It also included a link to the online questionnaire used to gather the necessary data for the study. Participants were given a 2-week timeframe to complete the questionnaire.

Since the 75 families included parents with more than one child in the SEP, and only one survey per family was required, the number of participants was reduced to 71 . Of the 48 respondents initially logging on to the online questionnaire, 40 completed it, approximately $56.34 \%$ of the total.

More than $90 \%$ of the questionnaires were completed by mothers. A large majority of the participants, especially fathers, were Caucasian (77.5\%), followed by Asian-Americans $(10 \%)$ and Latinos $(2.5 \%)$. English was the first language of a large majority of both respondents and their spouses, although other native languages included Japanese, Spanish, Chinese, Filipino, Thai, and Marathi. Along these lines, three mothers grew up using two languages (two of them English/Spanish and one English/Mandarin). More than half of both respondents and their spouses had some familiarity with Spanish, having studied it in the past, yet only $10 \%$ of them considered themselves able to understand the language and speak it fluently. Finally, all but one of the respondents and their spouses were highly educated, having earned university degrees.

\subsection{Instrument}

The questionnaire used in the project consisted of five sections, although the second and fourth sections, which asked participants respectively to describe their involvement in the Children's Center and in activities supporting Spanish outside of it, were excluded from the analyses as they pertained to a different project. As for the remaining sections, section 1 gathered information about participants' demographic data, namely their ethnic, linguistic, and educational backgrounds. Section 3 revolved around participants' opinions about the SEP's perceived linguistic, academic, cultural, and social benefits for their children. Lastly, section 5 focused on participants' opinions about some theoretical and practical tenets of the use of native languages with ELLs. Sections 1 and 3 contained the items used by Ramos (2007) when investigating parents' opinions about two-way bilingual education. Section 5, on the other hand, contained the items used by Ramos in his studies of teachers' opinions about the use of primary language instruction with language minority students while learning English (Ramos, 2009; 2005; 2001). The final survey was handed to colleagues of one of the coauthors to ensure the clarity and comprehensibility of the items. 


\subsection{Data Analysis}

The first section of the questionnaire required participants to either check the most appropriate response among those supplied or to provide additional data. Sections 3 and 5, for their part, asked participants to rate their responses on a 5-point Likert scale, ranging from "Strongly agree" to "Strongly disagree," with "Not sure" as the midpoint. To facilitate data analyses, these options were later collapsed into "Strongly agree/Agree", "Not sure", and "Disagree/Strongly disagree", as they were simply reflective of participants' either positive, neutral, or negative perceptions of the use of native languages in the classroom.

An exploratory factor analysis of the items in Section 3 resulted in three factors, roughly corresponding to Opinions about Spanish, Opinions about the SEP, and Parental support (see Table 1). As can be seen, while items 3.4 and 3.1 loaded almost equally onto the first two factors, their subsequent exclusion from further analysis did not modify the loadings substantially. Removing item 3.4 did not affect the reliability coefficient for the first factor ( $\alpha=.923$ ), while the removal of item 3.1 only impacted the reliability coefficient for the second factor slightly (from $\alpha=.903$ to $\alpha=.892$ ). The lower reliability for the third factor $(\alpha=.648)$ might have been due to the limited number of items in it.

Table 1. Exploratory Factor Analysis Section 3

\begin{tabular}{cccc}
\hline \multirow{2}{*}{ Question Number } & \multicolumn{3}{c}{ Component } \\
\cline { 2 - 4 } 3.11 & .878 & .215 & .182 \\
3.12 & .818 & .320 & .345 \\
3.13 & .806 & .364 & .185 \\
3.10 & .805 & .412 & .242 \\
3.9 & .773 & .454 & .207 \\
3.2 & .745 & .363 & .054 \\
3.14 & .687 & .159 & .315 \\
3.4 & .623 & .512 & -.027 \\
3.7 & .093 & .891 & .151 \\
3.8 & .391 & .797 & .250 \\
3.5 & .422 & .788 & -.065 \\
3.6 & .396 & .715 & -.045 \\
3.3 & .375 & .706 & .119 \\
3.1 & .538 & .609 & .063 \\
3.16 & .212 & .017 & .806 \\
3.17 & .056 & .209 & .750 \\
3.15 & .222 & -.044 & .731 \\
\hline & & &
\end{tabular}


In order to analyze participants' responses to Section 5, items 1, 2, 3, 4, 9, and 11 were labeled "Theory," while items 5, 6, 7, 8, and 10 were labeled "Practice," following in the footsteps of previous studies by Ramos (2001) and Karathanos (2009). The items in the "Practice" component were recoded in subsequent data analyses. Coefficient alpha reliability analyses showed high reliability for both the "Theory" $(\alpha=0.863)$ and "Practice" $(\alpha=0.881$ ) components, concurrent with previous findings by Ramos (2001) and Karathanos (2009). This allowed the creation of a composite score for each component to be used in correlation and t-test analyses.

Two variables were considered in the analyses: Level of education and Spanish proficiency. The researchers initially intended to cluster participants into three groups per their educational level ("Elementary/Middle/High school"; "Community College/Vocational school"; and "4-year college/Professional degree/Graduate school"). Yet, since all but one of the participants possessed university degrees, only one group was formed, which included all the parents. Similarly, since only four participants possessed native- or near-native ability in Spanish, the three original proficiency groups ("Can't understand or speak Spanish/ Can understand somewhat, but can't speak Spanish"; "Can understand and speak Spanish somewhat"; and "Can understand and speak Spanish well/very well/native-like ability") were reduced to two: "Can't understand or speak Spanish/Can understand somewhat but can't speak Spanish" and "Can understand and speak Spanish somewhat/well/very well/Native-/ Native-like ability" with 22 and 18 participants, respectively.

Reliability coefficients and correlations were calculated between the two variables ${ }^{1}$ (Level of education and Spanish proficiency) and the three factors in Section 3 (Opinions about Spanish, Opinions about the SEP, and Parental support) and the two components in Section 5 (Theory and Practice), respectively. Lastly, t-tests of independent samples were conducted to examine possible differences in the means of responses to the two components of Section 5 (Theory and Practice) between the two groups in which participants were clustered per their Spanish proficiency ("Can't understand or speak Spanish/Can understand somewhat but can't speak Spanish" and "Can understand and speak Spanish somewhat/well/ very well/Native-/Native-like ability”).

\section{FINDINGS}

In their responses to the questionnaire, most participants appeared to acknowledge the social, cultural, and intellectual advantages of learning Spanish for their children. Among them, the opportunity to interact with more people, the ability to participate in activities with members of other groups and learn about other cultures, and prospective career advantages (see Table 2).

${ }^{1}$ Proficiency in Spanish was treated as a continuous variable for this purpose. 
Table 2. Parents' Opinions About Learning Spanish

\begin{tabular}{lcccc}
\hline & \multicolumn{2}{c}{$\begin{array}{c}\text { Strongly agree/ } \\
\text { Agree }\end{array}$} & \multicolumn{2}{c}{ Not sure } \\
& $\mathrm{N}$ & $\%$ & $\mathrm{~N}$ & $\%$ \\
\hline $\begin{array}{l}\text { 3.9 Learning Spanish helps my child feel more } \\
\text { comfortable around Spanish speakers }\end{array}$ & 37 & 92.5 & 2 & 5.0 \\
$\begin{array}{l}\text { 3.10. Learning Spanish helps my child converse } \\
\text { with more people }\end{array}$ & 37 & 92.5 & 2 & 5.0 \\
$\begin{array}{l}\text { 3.11. Learning Spanish is important to better } \\
\text { understand Hispanic culture }\end{array}$ & 31 & 77.5 & 8 & 20.0 \\
$\begin{array}{l}\text { 3.12. Learning Spanish will help my child } \\
\text { participate in activities of other cultural groups }\end{array}$ & 34 & 85.0 & 3 & 7.5 \\
$\begin{array}{l}\text { 3.13. Learning Spanish is important for my child } \\
\text { because s/he may need it in his/her future career }\end{array}$ & 33 & 82.5 & 6 & 15.0 \\
$\begin{array}{l}\text { 3.14. Learning Spanish will make my child } \\
\text { smarter }\end{array}$ & 26 & 65.0 & 7 & 17.5 \\
\hline
\end{tabular}

Parents' opinions about the SEP, however, revealed some concerns. Thus, while around $60 \%$ of the parents agreed that the program helped children develop receptive and productive skills in Spanish, a very high $85 \%$ were willing to recommend the program to others, and $70 \%$ of them recognized the efforts of the faculty and staff to promote diversity and understanding among the community, $40 \%$ of them doubted the very faculty and staff's ability to address the school community's needs and concerns (Table 3). Overall, many parents were simply "not sure."

Correlations between participants' educational level and the three factors in Section 3 (Opinions about Spanish, Opinions about the SEP, Parental support) were not significant, while correlations between participants' Spanish proficiency and factors one and three were significant for those limited $(r(38)=.426, p=.006)$ and those fluent in Spanish $(r(38)=.641$, $\mathrm{p}=.000)$.

An independent samples t-test comparing participants' opinions about the same three factors in Section 3 by Spanish proficiency showed significant differences in participants' responses to the first factor, Opinions about Spanish, among those less proficient $(M=3.8626$, $S D=.85202)$ and those more proficient in the language $(M=4.4365, S D=.46089) ; t(38)=-2.564$, $p=.014$. Similarly, significant differences were also found in participants' responses to the third factor, Parental support, among those less proficient $(M=2.4773, S D=.63474)$ and those more proficient in Spanish $(M=3.3148, S D=.76245)$; $t(38)=-3.793, p=.001$. 
Table 3. Parents' Opinions About the Spanish Enrichment Program

\begin{tabular}{|c|c|c|c|c|}
\hline & \multicolumn{2}{|c|}{$\begin{array}{c}\text { Strongly agree/ } \\
\text { Agree }\end{array}$} & \multicolumn{2}{|c|}{ Not sure } \\
\hline & $\mathrm{N}$ & $\%$ & $\mathrm{~N}$ & $\%$ \\
\hline 3.3. The SEP helps children communicate in Spanish & 25 & 62.5 & 13 & 32.5 \\
\hline $\begin{array}{l}\text { 3.5. The SEP's faculty/staff are successful in balancing } \\
\text { the needs and concerns of the Center's linguistic } \\
\text { communities }\end{array}$ & 23 & 57.5 & 16 & 40.0 \\
\hline $\begin{array}{l}\text { 3.6. The SEP's faculty and staff have been successful in } \\
\text { promoting diversity and understanding among the school } \\
\text { community }\end{array}$ & 28 & 70.0 & 11 & 27.5 \\
\hline 3.7. The SEP helps children understand Spanish & 24 & 60.0 & 14 & 35.0 \\
\hline 3.8. I would recommend the Sep to others & 34 & 85.0 & 5 & 12.5 \\
\hline
\end{tabular}

Participants' responses to the items in Section 5 offered a wide array of responses (see Table 4). Thus, consistently with their favorable view of Spanish and the SEP, more than three-fourths of respondents acknowledged the impact of bilingualism on cognitive development (item 11); yet only around half of them recognized the role of primary language literacy (items 3 and 9) and knowledge (items 2 and 4) on ELLs' transition to English and an even smaller percentage supported developing ELLs' primary language literacy to accelerate this process (item 1). The two items receiving the least amount of support, items 1 and 9, referred to the impact of primary language literacy development on students' linguistic and academic success. Interestingly, item 1 received less support than item 9, despite their only difference being the latter being worded from a more theoretical standpoint. A similar situation occurred with items 2 and 4, both of which made reference to the transfer of knowledge between languages.

Responses to the "Practice" component revealed a confusing view of the instructional use of two languages in the classroom. Thus, while participants did not appear to support restricting the use of languages other than English in the classroom (items 6 and 7), or to have negative opinions about language and content instruction delivered in primary languages (items 8 and 5, respectively), support for these items was not strong. Along the same lines, while nearly two-thirds of the participants thought that exposure to two languages did not confuse students (item 10), only half and one-third of them, respectively, rejected the notion that using the primary language had a negative impact on ELLs' acquisition of English (items 5 and 8). Lastly, half of the participants disapproved the discontinuation of the primary language once ELLs had learned English (item 6), yet nearly two-thirds of them supported the placement of ELLs in classes without primary language support (item 7).

Overall, a large number of parents were "not sure". In fact, except for item 11, a majority of responses in this regard ranged from $37.5 \%$ to $45 \%$. This wide array of responses appears to indicate a limited understanding of the tenets, foundation, and practices of bilingualism. 
Table 4. Responses to "Theory" and "Practice"

\begin{tabular}{|c|c|c|c|c|c|c|}
\hline & \multicolumn{2}{|c|}{$\begin{array}{c}\text { Strongly } \\
\text { agree/agree }\end{array}$} & \multicolumn{2}{|c|}{ Not sure } & \multicolumn{2}{|c|}{$\begin{array}{l}\text { Strongly } \\
\text { disagree / } \\
\text { disagree } \\
\end{array}$} \\
\hline & $\mathrm{N}$ & $\%$ total & $\mathrm{N}$ & $\%$ total & $\mathrm{N}$ & $\%$ total \\
\hline $\begin{array}{l}\text { 1. ELLs not proficient in English would do } \\
\text { better in school if they first learn to read } \\
\text { and write in their L1. }\end{array}$ & 15 & 37.5 & 18 & 45.0 & 6 & 15.0 \\
\hline $\begin{array}{l}\text { 2. Using the L1 allows ELLs to base their } \\
\text { learning of English on the knowledge they } \\
\text { possess in their L1. }\end{array}$ & 22 & 55.0 & 15 & 37.5 & 2 & 5.0 \\
\hline $\begin{array}{l}\text { 3. ELLs who can read and write in their L1 } \\
\text { will learn English faster and more easily } \\
\text { than those who cannot read and write in } \\
\text { their L1 }\end{array}$ & 21 & 52.5 & 17 & 42.5 & 1 & 2.5 \\
\hline $\begin{array}{l}\text { 4. Learning subject matter in L1 helps ELLs } \\
\text { learn subject matter better in English. }\end{array}$ & 21 & 52.5 & 17 & 42.5 & 1 & 2.5 \\
\hline $\begin{array}{l}\text { 9. L1 literacy development facilitates ELLs' } \\
\text { development of English reading and } \\
\text { writing skills. }\end{array}$ & 18 & 45.0 & 21 & 52.5 & 0 & 0 \\
\hline $\begin{array}{l}\text { 11. High literacy levels in two languages } \\
\text { result in higher development of } \\
\text { knowledge or mental skills. }\end{array}$ & 31 & 77.5 & 7 & 17.5 & 0 & 0 \\
\hline
\end{tabular}

\begin{tabular}{|c|c|c|c|c|c|c|}
\hline & \multicolumn{2}{|c|}{$\begin{array}{c}\text { Strongly agree/ } \\
\text { agree }\end{array}$} & \multicolumn{2}{|c|}{ Not sure } & \multicolumn{2}{|c|}{$\begin{array}{c}\text { Strongly } \\
\text { disagree/ } \\
\text { disagree }\end{array}$} \\
\hline & $\mathrm{N}$ & $\%$ total & $\mathrm{N}$ & $\%$ total & $\mathrm{N}$ & $\%$ total \\
\hline $\begin{array}{l}\text { 5. L1 core curriculum instruction will result } \\
\text { in poor levels of English because ELLs } \\
\text { will use their L1 instead of English. }\end{array}$ & 6 & 15.0 & 19 & 47.5 & 13 & 32.5 \\
\hline $\begin{array}{l}\text { 6. L1 class use should stop as soon as ELLs } \\
\text { learn English. }\end{array}$ & 4 & 10.0 & 15 & 37.5 & 20 & 50.0 \\
\hline $\begin{array}{l}\text { 7. If an ELL is in an EO class he/she will } \\
\text { learn English better. }\end{array}$ & 10 & 25.0 & 15 & 37.5 & 14 & 35.0 \\
\hline $\begin{array}{l}\text { 8. Using the L1 in class will have a negative } \\
\text { effect on ELLs' ability to learn English. }\end{array}$ & 6 & 15.0 & 13 & 32.5 & 20 & 50.0 \\
\hline $\begin{array}{l}\text { 10. Teaching ELLs in both English and their } \\
\text { L1 will confuse them. }\end{array}$ & 3 & 7.5 & 12 & 30.0 & 24 & 60.0 \\
\hline
\end{tabular}


Correlations between participants' level of education and the "Theory" component showed moderate significance $(r(38)=.359, p=.025)$, while correlations between the same variable and the "Practice" component, as well as between participants' Spanish proficiency and the "Theory" and "Practice" were not significant. Finally, the results of a t-test of independent samples, examining participants' opinions about "Theory" and "Practice" by Spanish proficiency showed no significant differences between those more or less proficient in the language.

\section{Discussion}

Most participants in the present project were Caucasian, monolingual English-speakers, and all but one highly educated. Hence, their a priori advantageous linguistic and professional status offered a chance to gain perspectives differing significantly from previous studies on parents' attitudes toward children learning a second language. In a large majority of these studies, participants belonged to ethnic, cultural, and linguistic minorities (e.g., Lao, 2004; Ramos, 2007).

Overall, the findings of the project resemble those of previous studies (King and Fogle, 2006; Ramos, 2007), in that participants seemed to appreciate the academic, linguistic, and intellectual advantages of children's exposure to second languages and development of bilingualism. Among them, improving their fluency in a second language and achieving a better understanding of the culture, more opportunities to communicate with other speakers, developing a stronger sense of identity, and increasing future job prospects. However, a concerning issue for SEP's administrators should be the large number of participants who were "not sure" that the program increased children's receptive and productive skills in Spanish, or effectively addressed the needs of the different communities involved in the Center.

Making a concerted effort to investigate the reasons for these hesitations should become, consequently, a priority of the SEP's and the Center's faculty and staff. Holding recurrent informational meetings to educate parents on the rationale, tenets, and goals of the SEP, setting realistic expectations about children's progress in Spanish given the constrains of the program, and pointing to additional sources of Spanish input outside the Center would undoubtedly be good moves. Additionally, the creation of an inviting atmosphere that increases parental participation, involvement, and understanding of the program will improve the home-school connection, an essential contributor to the success of second language programs (López, 2013).

Participants' views about ELLs' development of bilingualism, on the other hand, were consistent with previous research (e.g., Shin and Krashen, 1996; Ramos, 2007), in that they showed more support for its "Theory" than for its "Practice" components; furthermore, overall support was not as strong as in past studies. In fact, only the item on the intellectual benefits of bilingualism was supported by a large majority of the parents; support for the remaining items ranged from around $33 \%$ to slightly more than $50 \%$ of the responses.

Notwithstanding, a most concerning issue was the number of "not sure" responses, largely surpassing that of previous research on the issue (e.g., Lao, 2004; Ramos, 2007; Shin and Krashen, 1996). One possible explanation might be that respondents in other studies were more aware of the principles of language acquisition. It might also be that they had witnessed firsthand the impact of their own primary languages on their own, or their 
children's, acquisition of English. In any case, despite the limited second language experience of the parents in the present study, their high educational levels and their experiences witnessing their children progress in Spanish in the SEP might lead observers to think that they had gained a basic understanding of the principles of native language instruction. Yet, their apparent lack of knowledge in this regard makes it necessary to continue to stress the need to educate stakeholders on the principles and practices of bilingualism.

Finally, some may view the participants in this project as likely representatives of elite bilingualism (Fishman, Nahirny, Hoffman, and Hayden, 1966), in that majority speakers of a language sought the benefits of second language acquisition for their children, while holding a different perception of the use of minority languages with language minority students, in this case ELLs. However, it seems necessary to note that the parents' responses to the questionnaire did not show their frontal opposition to their children's, or to ELLs', exposure to a minority language, either in early childhood or during their school years; rather, they appeared to show a fundamental lack of understanding of this phenomenon, a weakness that must be remediated in order to clarify misconceptions and increase support for bilingualism and bilingual practices.

\section{Conclusions AND implications}

The results of this project revealed that a large majority of participants supported the SEP for what they envisioned as the future benefits of bilingualism for their children. On the other hand, support for the maintenance or development of bilingualism among ELLs did not seem as strong. Overall, parents did not seem aware of the inner workings of the SEP, the intricacies of bilingualism, or the role of the native language in second language acquisition.

While the findings of this study are limited to the responses of its participants, they offer important insights for bilingual education advocates. Among them, the need to continue to disseminate information among stakeholders about the underlying tenets of bilingualism and bilingual education. Parents, especially, are a critical resource that cannot be overlooked. Parents who are informed about this issue can more comfortably advocate for higher academic and linguistic standards, adequate materials and resources, and increasing funding for second or foreign language education programs in schools.

Secondly, it seems necessary to continue to disseminate information about the principles and practices of second language acquisition and bilingualism among the general public. If highly educated parents invested in exposing their children to a second language since early childhood seemed uninformed about second language acquisition in general, what can be realistically expected from individuals with no children, no children in the school system, or no access to reputable sources of information? A concerted effort to spread knowledge about the principles and practices of second language acquisition and bilingualism until they become commonplace in our society is necessary to help erase existing misunderstandings and urban legends surrounding the phenomenon (Shin, 2010). Unfortunately, as the present study reveals, much work is still necessary to accomplish this. 


\section{REFERENCES}

Adi-Japha, E., Berberich-Artzi, J., and Libnawi, A. (2010). "Cognitive flexibility in drawings of bilingual children", in Child Development, 81: 1356-1366.

Anderson, J., Anderson, A., and Sadiq, A. (2017). "Family literacy programmes and young children's language and literacy development: Paying attention to families' home language", in Early Child Development and Care, 187, 3-4: 644-654.

Barnett, W. S., Yarosz, D. J., Thomas, J., Jung K., and Blanco, D. (2006). "Two-way and monolingual English immersion in preschool education: An experimental comparison", in Early Childhood Research Quarterly, 22: 277-293.

Bialystok, E. and Senman, L. (2004). "Executive processes in appearance-reality tasks: The role of inhibition of attention and symbolic representation", in Child Development, 75, 2: 562-579.

Bialystok, E. (2001). Bilingualism in development. New York: CUP.

Bialystok, E. (2011). "Coordination of executive functions in monolingual and bilingual children", in Journal of Experimental Child Psychology, 110: 461-468.

Bialystok, E. (2011). "Reshaping the mind: The benefits of bilingualism", in Canadian

Journal of Experimental Psychology, 65: 229-235.

Carlson, S. M., and Meltzoff, A. N. (2008). "Bilingual experience and executive function in young children", in Developmental Science, 11: 282-298.

Chang, F., Crawford, G., Early D., Bryant, D., Howes, C., Burchinal, M., and Pianta, R. (2007). "Spanish-speaking children's social and language development in pre-kindergarten classrooms", in Early Education and Development, 18: 243-269. http://dx.doi. org/10.1080/10409280701282959

Díaz, R. M., Padilla, K. A., and Weathersby, E. K. (1991). "The effects of bilingualism on preschoolers' private speech", in Early Childhood Quarterly, 6: 377-393.

EdGov (2014). "ED Data Express: Data about elementary and secondary schools in the U.S", available from: http://eddataexpress.ed.gov/statereport.cfm?state=US \&submit.x=40\&submit. $y=6$, accessed 17 September, 2017.

Farruggio, P. (2010). "Latino immigrant parents' views of bilingual education as a vehicle for heritage preservation", in Journal of Latinos and Education, 9, 1: 3-21.

Ferjan Ramírez, N., and Kuhl, P. (2017). "Bilingual baby: Foreign language intervention in Madrid's infant education centers", in Mind, Brain, and Education, 11, 3: 133-143.

Fishman, J., Nahirny, V., Hofman, J., and Hayden, R. (1966). Language loyalty in the United States. The Hague: Mouton and Company.

Garcia, E., \& McLaughlin, B, (Eds.) [with Spodek, B. and Saracho, O. N.]. (1995). Meeting the challenge of linguistic and cultural diversity in early childhood education. New York, NY: Teachers College Press.

Gerard, M. (2005). "Bridging the gap: Towards an understanding of young children's thinking in multiage groups", in Journal of Research in Childhood Education, 19, 3: 243-250.

Gerena, L. (2011). "Parental voice and involvement in cultural context: Understanding rationales, values, and motivational constructs in a dual immersion setting", in Urban Education, 46, 3: 342-370.

Greenberg, A., Bellana, B., and Bialystok, E. (2013). "Perspective-taking ability in bilingual children: Extending advantages in executive control to spatial reasoning", in Cognitive Development, 28: 41-50.

Greene, J. P. (1997). "A meta-analysis of the Rossell and Baker review of bilingual education research", in Bilingual Research Journal, 21, 2-3: 103-122. 
Halle, T. G., Whittaker, J.V., Zepeda, M., Rothernberg, L., Anderson, R., Daneri, P., and Buysse, V. (2014). "The social emotional development of dual language learners: Looking back at existing research and moving forward with purpose", in Early Childhood Research Quarterly, 29, 734-749.

Harrison, D. (2007). When languages die. Oxford, England: Oxford University Press.

Karathanos, K. (2009). "Exploring U.S. mainstream teachers' perspectives on use of the native language in instruction with English language learner students", in International Journal of Bilingual Education and Bilingualism, 12, 6: 615-633.

Kibler, A. K., and Roman, D. (2013). "Insights into professional development for teachers of ELLs: A focus on using students' native languages in the classroom", in Bilingual Research Journal, 36: 187-207.

King, K., and Fogle, L. (2006). "Bilingual parenting as good parenting: Parents' perspectives on family language policy for additive bilingualism", in The International Journal of Bilingual Education and Bilingualism, 9, 6: 695-712.

Kovacs, A. M., and Mehler, J. (2009). "Cognitive gains in 7-month-old bilingual infants", in Proceedings of the National Academy of Sciences, 106: 6556-6560.

Krashen, S. D. (2004). The power of reading: Insights from the research ( $2^{\text {nd }}$ ed.). Portsmouth, NH: Heinemann.

Krashen, S., and McField, G. (2005). "What works? Reviewing the latest evidence on bilingual education", in Language Learner, 1, 2: 7-10, 34.

Lao, C. (2004) "Parents' attitudes toward Chinese-English bilingual education and Chinese-language use", in Bilingual Research Journal, 28, 1: 99-121.

Lee, J. S., and Jeong, E. (2013). "Korean-English dual language immersion: Perspectives of students, parents and teachers", in Language, Culture and Curriculum, 26, 1: 89-107, DOI: 10.1080/07908318.2013.76589

López, M. M. (2013). "Mothers choose: Reasons for enrolling their children in a two-way immersion program", in Bilingual Research Journal, 36: 208-227.

Marian, V., Shook, A., and Schroeder, S. R. (2013). "Bilingual two-way immersion program benefits academic achievement", in Bilingual Research Journal, 36, 2: 167-186.

McCardle, P. (2015). "Bilingualism: Research and practice", in New Directions for Child and Adolescent Development, 147: 41-48.

McField, G., and McField, D. (2014). "The consistent outcome of bilingual education programs: A meta-analysis of meta-analyses", in G. McField (ed.), The miseducation of English learners. Charlotte, NC: Information Age, 267-299.

Müller, N. (1998). "Transfer in bilingual first language acquisition", in Bilingualism: Language and Cognition, 1: 151-171.

National Center for Research on Cultural Diversity and Second Language Learning (1994). "Two-way bilingual education programs in practice: A national and local perspective", in ERIC Digest, 12: 1-7.

Oller, D. K., and Jarmulowicz, L. (2007). "Language and literacy in bilingual children in the early school years", In E. Hoff, \& M. Shatz (eds.), Blackwell handbook of language and development. Malden, MA: Blackwell Publishing, 368-386.

Oliva-Olson, C., Estrada, M., and Edyburn, K. L. (2017). "Preparing California's early care and education workforce to teach young dual language learners", in Issues in Teacher Education, 26, 2: 87-113.

Ovando, C. J., Collier, V. P., and Combs, M. C. (2003). Bilingual and ESL classrooms: Teaching in multicultural contexts (3rd ed.). New York: McGraw Hill. 
Parkes, J., and Ruth, T. (2011). "How satisfied are parents of students in dual language education programs? 'Me parece maravillosa la gran oportunidad que le están dando a estos niños'”, in International Journal of Bilingual Education and Bilingualism, 14, 6: 701-718.

Poulin-Dubois, D., Blaye, A., Coutya, J., and Bialystok, E. (2011). "The effects of bilingualism on toddlers' executive functioning", in Journal of Experimental Child Psychology, 108: 567-579.

Ramírez, J. D. (1992). "Executive summary”, in Bilingual Research Journal, 16, 1-2: 1-62.

Ramos, F. (2001). "Teachers' opinions about the theoretical and practical aspects of the use of native language instruction for language minority students: A cross-sectional study", in Bilingual Research Journal, 25, 3: 357-374.

Ramos, F. (2005). "Spanish teachers' opinions about the use of Spanish in mainstream classrooms before and after their first year in California", in Bilingual Research Journal, 29, 2: 411-433.

Ramos, F. (2007). "What do parents think of two-way bilingual education? An analysis of responses", in Journal of Latinos and Education 6, 2: 139-150.

Ramos, F. (2009). "California/Spain Visiting Teachers Program participants' opinions about the use and effects of students' primary languages in the classroom", in International Multilingual Research Journal, 3, 2: 51-71.

Ramos, F., and Krashen, S. (2013). “Arnold's advantages: How Governor Schwarzenegger acquired English through de facto bilingual education", in International Multilingual Research Journal, 7: 220-229.

Rodríguez, M. V. (2015). "Families and educators supporting bilingualism in early childhood, in School Community Journal, 25, 2: 177-194.

Rodríguez, J. L., Díaz, R. M., and Durán, D. (1995). "The impact of bilingual preschool education on the language development of Spanish-speaking children", in Early Childhood Research Quarterly, 10: 475-490.

Romaine, S. (1995). Bilingualism, $2^{\text {nd }}$ ed. Oxford: Blackwell.

Ryan, A. M. (2005). "The effectiveness of the Manchester Even Start Program in improving literacy outcomes for preschool Latino Students", in Journal of Research in Childhood Education, 20, 1: 15-16.

Sachs, J. (2005). "Communication development in infancy", in J. B. Gleason (ed.), Development of Language. Boston, MA: Pearson, 31-61.

Schieffeling, B. B., and Ochs, E. (1986). "Language Socialization”, in Annual Review Anthropology, 15: 163-191.

Shin, S. J. (2010). Bilingualism in schools and society. NY: Routledge.

Shin, F., and Gribbons, B. (1996). "Hispanic parent perceptions and attitudes of bilingual education", in Journal of Mexican American Educators, 6: 16-22.

Shin, F., and Kim, S. (1998). "Korean parent perceptions and attitudes of bilingual education", In R. Endo, C. Park, J. Tsuchida, and A. Abbayani (Eds.), Current issues in Asian and Pacific American education. Covina, CA: Pacific Asian Press.

Shonkoff, J. A., and Phillips, D. (Eds). (2000). From neurons to neighborhoods. The science of early childhood development. Washington, DC: National Academies Press.

Shore, R. (1997). Rethinking the brain: New insights into early development. New York, NY: Families and Work Institute.

Tannenbaum, M. and Berkovich, M. (2005). "Family relations and language maintenance: Implications for language and educational policies", in Language Policy, 4, 287-309. 
Thomas, W. P., and Collier, V. P. (2002). A national study of school effectiveness for language minority students' long-term academic achievement. Santa Cruz, CA: Center for Research on Education, Diversity, and Excellence.

Worthy, J., and Rodriguez-Galindo, A. (2006). "Mi hija vale dos personas": Latino immigrant parents' perspectives about their children's bilingualism" in Bilingual Research Journal, 30, 2: 579-601.

Yang, S., Yang, H., and Lust, B. (2011). "Early childhood bilingualism leads to advances in executive attention: Dissociating culture and language". Bilingualism: Language and Cognition, 14(3), 412-422. 